\title{
FAKTOR-FAKTOR PENENTU MINAT MAHASISWA JURUSAN MANAJEMEN UNTUK BERWIRAUSAHA (Studi Mahasiswa Jurusan Manajemen Fakultas Ekonomi Universitas Santo Thomas Sumatera Utara)
}

\author{
Joana L. Saragih
}

\begin{abstract}
Abstrak
Tujuan penelitian, untuk mengetahui dan menganalisis faktor-faktor apa saja yang menentukan minat mahasiswa untuk berwirausaha dan menganalisis faktor mana yang lebih dominan yang menentukan minat mahasiswa untuk berwirausaha. Populasi penelitian seluruh mahasiswa Jurusan Manajemen Fakultas Ekonomi Universitas Katolik Santo Thomas Sumatera Utara. Sampel penelitian berjumlah 5 x n ( $\mathrm{n}=$ banyaknya faktor yang diamati) yang mengacu pada pendapat Hair . Maka jumlah sample sebanyak 5 x 24 faktor $=120$ mahasiswa. Metode pengumpulan data yaitu : wawancara (Interview), koesioner (questionaire) dan studi dokumentasi. Metode analisis dengan analisis factor. Hasil penelitian menunjukkan, dari 24 faktor yang yang dominan sebagai penentu minat mahasiswa jurusan manajemen untuk berwirausaha adalah : Faktor 1 : Keyakinan, Prestise, Pekerjaan orang tua, Tanggung jawab keluarga, Senang, Kebebasan Kebijakan pemerintah dan Kreatif ; Faktor 2 : Latar belakang kelurga, Status Sosial, Pesaing, Suka Tantangan, Kesempatan dan Inovatif ; Faktor 3 : Pendapatan, Kompetensi, Bertanggung Jawab, Modal, Optimis, Kreatif dan Kebijakan Pemerintah ; Faktor 4 ; Kepuasan , Pengalaman, Informasi dan Peluang. Untuk penelitian di masa mendatang sebaiknya menambah variabel yang akan dijadikan variabel penelitian yang diduga mempengaruhi minat mahasiswa berwirausaha. Untuk penelitian selanjutnya diharapkan peneliti dapat memperluas responden yang dijadikan sampel penelitian .
\end{abstract}

Kata kunci: Personal, Sociological, Environmental, Berwirausaha

\section{PENDAHULUAN}

Saat ini, hampir seluruh mahasiswa memiliki cita - cita untuk bekerja di suatu instansi baik pemerintah maupun swasta setelah menyelesaikan studinya di perguruan tinggi. Kondisi ini, berlaku hampir untuk seluruh mahasiswa di lembaga penyedia jasa pendidikan baik yang berstatus negeri maupun perguruan tinggi berstatus swasta. Selain itu, berbagai fenomena seperti fenomena banyaknya pengangguran yang semakin meningkat setiap harinya menjadi salah satu masalah sosial yang membutuhkan penyelesaian. Sedikitnya lapangan pekerjaan yang ada saat ini, menjadi alasan utama bertambahnya angka pengangguran di negara-negara berkembang seperti Indonesia. Ditambah lagi adanya kondisi yang menunjukan kecenderungan beberapa pabrik atau industri yang banyak merumahkan karyawannya karena mengalami kebangkrutan sebagai akibat 
dari berbagai regulasi dan kondisi makro ekonomi yang tidak pernah mampu untuk dihindari.

Dunia berwirausaha merupakan dunia tersendiri yang unik. dituntut selalu kreatif, inovatif, dan berdaya saing di setiap waktu. Tuntutantuntutan tersebut merupakan bentuk keharusan bagi seorang wirausahawan sebagaimana yang telah dicanangkan oleh Presiden Susilo Bambang Yudoyono di saat melakukan peringatan setahunnya Gerakan Kewirausahawan Nasional (GKN) pada 2 Februari 2011 ( Ani Murwani Muhar, 2013) Seseorang yang akan terjun menjadi wirausahawan kreatif, ia harus bekerja 24 jam sehari, dan 7 hari dalam seminggu. Hal semacam itu masih harus ia lakukan paling sedikit untuk kurun waktu kurang lebih 2 tahun pertama. Berjuang tanpa henti dengan berbagai tekanan fisik maupun psikis. Namun demikian, tuntutan untuk menjadi wirausahawan yang berhasil tersebut, bukanlah menjadi sesuatu yang sangat berat bagi seorang yang telah mengalami proses pembelajaran di bangku-bangku pendidikan secara benar. Untuk itu semua masyarakat khususnya kalangan mahasiswa yang memiliki kreativitas dan bekal ilmu yang telah diperolehnya di dunia perkuliahan, diyakini memiliki mental dan berpengatahuan untuk berwirausaha dibanding menggantungkan diri dengan berburu pekerjaan bersama jutaan pengangguran yang juga mencari kerja.

Terkait dengan fenomena tersebut di atas, maka untuk menjadikan mahasiswa memiliki jiwa-jiwa yang selayaknya dimiliki oleh seorang wirausahawan, maka diperlukan jiwa dan perilaku berwirausaha di kalangan para mahasiswa. Menurut Kourilsky dan Walstad dalam Ani Murwani Muhar (2013), para mahasiswa yang menerima pendidikan kewirausahaan selama di bangku kuliahnya, dipertimbangkan untuk menjadi calon-calon wirausahawan unggul di masa depan. Sikap, perilaku, dan pengetahuan mahasiswa tentang kewirausahaan akan membentuk kecenderungan mereka untuk membuka usaha-usaha baru di masa mendatang. Oleh karenanya, pemahaman dan hal-hal yang terkait faktor pendukung terbentuknya jiwa wirausahaan menjadi permasalahan penting untuk diteliti.

Dalam hubungannya dengan alasan dan pertimbangan di atas, mahasiswa sebagai salah satu golongan elit masyarakat yang diharapkan menjadi pemimpin-pemimpin bangsa masa depan, sudah sepantasnya menjadi pelopor dalam mengembangkan semangat kewirausahaan. Alma (2010) menyatakan dengan bekal pendidikan tinggi yang diperoleh di bangku kuliah dan idelisme yang terbentuk, lulusan Perguruan Tinggi diharapkan mampu mengembangkan diri menjadi seorang wirausahawan 
dan bukan sebaliknya lulusan Perguruan Tinggi hanya bisa menunggu lowongan kerja bahkan menjadi pengangguran yang pada hakekatnya merupakan beban pembangunan.

Dirjen Pendidikan Tinggi (DIKTI) mencanangkan program kewirausahaan mahasiswa menjadi prioritas nasional (Ani Murwani Muhar 2013), sebagai upaya pembenahan sistem pendidikan agar terjadi keselarasan antara pendidikan dan dunia kerja. Peranan perguruan tinggi diperlukan untuk memberikan informasi, pengetahuan, pemahaman tentang kewirausahaan serta memberikan wadah bagi mahasiswa untuk berwirausaha. Faktor yang mempengaruhi seseorang terdorong untuk berwirausaha adalah kepribadian dan aspek lain seperti faktor usia, pendidikan, lingkungan keluarga dan pergaulan(Nasution, 2001). Muladi (2011) menyatakan seseorang termotivasi menjadi wirausaha karena adanya faktor kesempatan, kebebasan dan kepuasan dalam menjalani hidup.

Universitas Katolik Santo Thomas sebagai salah satu Perguruan Tinggi swasta yang ada di Sumatera Utara telah cukup lama membekali para mahasiswanya untuk menjadi wirausaha melalui mata kuliah kewirausahaan, khususnya para mahasiswa yang mengambil Fakultas Ekonomi, jurusan manajemen. Sejumlah aktivitas telah dilakukan melalui mata kuliah, yaitu tentang teori- teori kewirausahaan dan praktek kewirausahaan. Maka peneliti tertarik untuk meneliti dengan judul : Faktor-Faktor Penentu Minat Mahasiswa Jurusan Manajemen Untuk Berwirausaha (Studi Mahasiswa Jurusan Manajemen Fakultas Ekonomi Universitas Santo Thomas Sumatera Utara).Berdasarkan latar belakang dan penelitian sebelumnya, maka masalah penelitian dirumuskan : faktor faktor apa saja yang dominan menentukan minat mahasiswa untuk berwirausaha.

\section{TINJAUAN PUSTAKA}

\section{Pengertian Wirausaha}

Menurut Fuadi (2009) seorang entrepreneur atau wirausahawan adalah orang yang mempunyai kemampuan melihat dan menilai kesempatan-kesempatan bisnis, mengumpulkan sumber-sumber daya yang dibutuhkan guna mengambil keuntungan dari padanya dan mengambil tindakan yang tepat guna memastikan kesuksesan.

Berdasarkan pengertian wirausaha di atas, maka wirausaha adalah setiap orang yang memulai sesuatu bisnis baru, bisa memanfaatkan peluang dengan menggunakan waktu yang disertai modal dan resiko serta 
menerima balas jasa. Hal tersebut menunjukan bahwa wirausaha tidak hanya mengandalkan modal saja.

\section{Pengertian Minat Wirausaha}

Menurut Yanto, minat wirausaha adalah kemampuan untuk memberanikan diri dalam memenuhi kebutuhan hidup serta memecahkan permasalahan hidup, memajukan usaha atau menciptakan usaha baru dengan kekuatan yang ada pada diri sendiri. Hal yang paling utama yaitu sifat keberanian untuk menciptakan usaha baru. Menurut Santoso, minat wirausaha adalah gejala psikis untuk memusatkan perhatian dan berbuat sesuatu terhadap wirausaha itu dengan perasaan senang karena membawa manfaat bagi dirinya. Inti dari pendapat tersebut adalah pemusatan perhatian yang disertai rasa senang (Suryana, 2008: 22)

Penelitian Purwinarti(2006:18), minat wirausaha adalah kecenderungan hati dalam diri subjek untuk tertarik menciptakan suatu usaha yang kemudian mengorganisir, mengatur, menanggung risiko dan mengembangkan usaha yang diciptakannya tersebut. Minat wirausaha berasal dari dalam diri seseorang untuk menciptakan sebuah bidang usaha.

Menurut Fuadi (2009:93), "Minat berwirausaha adalah keinginan, ketertarikan, serta kesediaan untuk bekerja keras atau berkemauan keras untuk berusaha secara maksimal untuk memenuhi kebutuhan hidupnya tanpa merasa takut dengan resiko yang akan terjadi, serta berkemauan keras untuk belajar dari kegagalan."

Berdasarkan definisi di atas, maka yang dimaksud dengan minat wirausaha adalah keinginan, ketertarikan serta kesediaan untuk bekerja keras atau berkemauan keras dengan adanya pemusatan perhatian untuk berusaha memenuhi kebutuhan hidupnya tanpa merasa takut akan resiko yang akan dihadapi, senantiasa belajar dari kegagalan yang dialami, serta mengembangkan usaha yang diciptakannya.

\section{Cara Menjadi Seorang Wirausaha Sukses}

Menurut Murphy \& Peck (H. Buchari Alma, 2010: 82-85), menggambarkan delapan anak tangga untuk mencapai puncak karir. Delapan anak tangga ini dapat pula digunakan oleh wirausaha dalam mengembangkan profesinya.

a. Mau Kerja Keras (Capacity for Hard Work)..

b. Bekerjasama dengan Orang Lain (Getting Things Done With and Through People).

c. Penampilan yang Baik (Good Appearance). 
d. Yakin (Self Confidence).

e. Pandai Membuat Keputusan (Making Sound Decision).

f. Mau Menambah Ilmu Pengetahuan (College Education).

g. Ambisi untuk Maju (Ambition Drive). Kita harus punya semangat tinggi, mau berjuang untuk maju. Orang yang gigih dalam menghadapi pekerjaan dan tantangan, biasanya banyak berhasil dalam kehidupan.

h. Pandai Berkomunikasi (Ability to communicate)..

\section{Keterampilan Berwirausaha}

Menurut Suryana, (2008), ketrampilan yang harus dimiliki seseorang yang berjiwa wirausaha yaitu :

1. Keterampilan berpikir Kreatif..

2. Keterampilan dalam Pembuatan Keputusan.

3. Keterampilan dalam Kepemimpinan.

\section{Faktor-faktor Yang Mempengaruhi Minat Berwirausaha}

Alma (2007:9) menyatakan terdapat 3 faktor utama yang menentukan minat berwirausaha tersebut yaitu:

1. Personal. Personal

2. Sociological. Sociological yaitu menyangkut masalah hubungan dengan family dan hubungan sosial lainya. kepada orang tua, saudara, keluarga yang lain (kakek, paman, bibi, anak), teman-teman, pasangan, atau pengusaha sukses yang diidolakanya. Dorongan teman berpengaruh terhadap semangat berwirausaha, karena kita dapat berdiskusi dengan bebas, dibandingkan orang lain.

3. Environmental. Environmental yaitu menyangkut hubungan dengan lingkungan.

\section{Beberapa Pandangan Tentang Minat Mahasiswa Berwirausaha}

Masalah kewirausahaan di lingkungan mahasiswa, telah banyak pihak yang mencoba untuk mengkajinya. Terkait intensi kewirausahaan, Katz dan Gartner (1988) dalam Ani Murwani Muhar (2013) menjelaskan sebagai suatu proses pencarian informasi guna pencapaian tujuan usaha. Pandangan tersebut menunjukan adanya suatu bentuk keunggulan bagi mereka yang berusaha dengan tingkat intensi yang tinggi. Artinya, para wirausahawan akan memiliki keunggulan bersaing manakala mereka memiliki intensi yang tinggi. Pandangan ini telah mendukung hasil kajian yang dilakukan oleh Krueger dan Carsrud (1993) dalam Ani Murwani Muhar (2013). 
- Faktor Kepribadian.

- Efikasi Diri.

- Sebuah hasil kajian (Natilawati, 2004) menunjukan bahwa terdapat beberapa ciri seorang individu yang memiliki efikasi diri tinggi. Ciri-ciri tersebut diantaranya adalah:

1. Bertanggung jawab secara pribadi,

2. Mengharapkan hasil yang diperoleh dari kemampuan optimal diri sendiri,

3. Suka akan rintangan dan kurang menyukai sebuah tugas yang memiliki tantangan yang rendah,

4. Sangat menghargai waktu sehingga individu tersebut mengerjakan semua yang dapat dikerjakannya saat ini atau tidak suka menangguhkan sebuah pekerjaan,

5. Memiliki daya kreativitas dan inovatif yang tinggi.

6. Menyukai segala sesuatu yang mengandung resiko karena individu percaya diri dan,

7. Memiliki keyakinan yang tinggi.

Selain pencirian di atas, Bandura (1986) dalam Ani Murwani Muhar, (2013) , juga menambahkan bahwa individu yang memiliki efikasi diri juga akan memiliki pengaruh yang signifikan terhadap usaha dan ketegaran diri dalam menghadapi setiap kesulitan. Individu yang memiliki efikasi diri yang tinggi akan melihat tugas-tugas sulit sebagai suatu tantangan yang harus dihadapi dan bukan suatu ancaman untuk dihindari. Oleh karenanya, semakin tinggi seseorang memiliki efikasi diri, maka semakin tinggi pula dirinya memiliki keinginan atau niat/intensi untuk mencapai tujuannya. Kondisi yang demikian merupakan salah satu dari beberapa syarat keberhasilan berwirausaha.

- Faktor Lingkungan.

- Faktor Demografi . Menurut Tinambunan (2010) dalam Titik Purwinarti (2006) mengatakan bahwa salah satu faktor kunci intensi kewirausahaan adalah demografis. Beberapa variabel yang menjadi bagian dari faktor demografis ini adalah pengalaman, tingkat pendidikan, dan usia. Sedangkan Mazzarol et.al. (1999) menjelaskan bahwa faktor - faktor demografi.

\section{Penelitian sebelumnya}

Terdapat beberapa penelitian sebelumnya tentang fektor-faktor yang mempengaruhi minat seseorang untuk berwirausaha (http://digilib.its.ac.id/ public /ITS -Undergraduate-13441-Paper.pdf) yaitu : 
1. Cholisi (1991) : ada pengaruh positif antara latar belakang keluarga mahasiswa dengan pekerjaan kewirausahaan terhadap motivasi usaha dan usaha mandiri mahasiswa ITS.

2. Meynita (2006) : adanya pengaruh antara pola asuh orang tua secara demokratis terhadap pembentukan jiwa wirausaha menggunakan metode Structural Equation Modelling (SEM), studi kasus mahasiswa Teknik Industri ITS.

3. Yohnson (2003), mengemukakan bahwa terdapat faktor-faktor lain yang memotivasi seseorang untuk menjadi wirausaha yaitu faktor kesempatan, faktor kebebasan dan faktor kepuasan menjalani hidup.

\section{METODE PENELITIAN}

\section{Jenis Penelitian}

Jenis penelitian ini adalah penelitian deskriptif yang didasarkan atas survey terhadap objek penelitian.

\section{Populasi dan Sampel}

Populasi dalam penelitian ini adalah seluruh mahasiswa jurusan manajemen Fakultas Ekonomi Universitas Katolik Santo Thomas Sumatera Utara. Sampel penelitian ini berjumlah $5 \times \mathrm{n}(\mathrm{n}=$ banyaknya faktor yang diamati) yang mengacu pada pendapat Hair . Maka jumlah sample sebanyak $5 \times 24$ faktor $=120$ mahasiswa. Metode pengambilan sample digunakan yaitu purposive sampling.

\section{Definisi Operasional dan Pengukuran Variabel}

Definisi operasional variabel dalam penelitian ini yaitu :

Tabel 1. Definisi Operasional Variabel Dalam Penelitian

\begin{tabular}{|c|c|c|c|c|}
\hline No & Variabel & Defenisi & Referensi & $\begin{array}{c}\text { Skala } \\
\text { Pengukuran }\end{array}$ \\
\hline 1 & $\begin{array}{c}\text { Faktor } \\
\text { Personal }\end{array}$ & $\begin{array}{l}\text { Menyangkut aspek-aspek } \\
\text { kepribadian seseorang } \\
\text { yang dapat mempengaruhi } \\
\text { minat berwirausaha }\end{array}$ & $\begin{array}{l}\text { 1. Kebebasan } \\
\text { 2. Pendapatan } \\
\text { 3. Senang } \\
\text { 4. Kepuasan } \\
\text { 5. Prestise } \\
\text { 6. Kompetensi } \\
\text { 7. Keyakinan } \\
\text { 8. Optimis } \\
\text { 9. Suka Tantangan } \\
\text { 10. Inovatif }\end{array}$ & Ordinal \\
\hline
\end{tabular}




\begin{tabular}{|c|c|c|c|c|}
\hline No & Variabel & Defenisi & Referensi & $\begin{array}{c}\text { Skala } \\
\text { Pengukuran }\end{array}$ \\
\hline & & & $\begin{array}{ll}11 . & \text { Tanggung Jawab } \\
\text { 12. } & \text { Pengalaman } \\
\text { 13. } & \text { Kreatif } \\
\end{array}$ & \\
\hline 2 & $\begin{array}{l}\text { Faktor } \\
\text { Sociologic } \\
\quad \text { al }\end{array}$ & $\begin{array}{l}\text { Menyangkut aspek-aspek } \\
\text { sosial yang mempengaruhi } \\
\text { minat seseorang untuk } \\
\text { berwirausaha }\end{array}$ & $\begin{array}{l}\text { 1. Hubungan keluarga } \\
\text { 2. Pekerjaan orang tua } \\
\text { 3. Status Sosial } \\
\text { 4. Tanggung jawab } \\
\text { keluarga } \\
\text { 5. Latar belakang kelurga }\end{array}$ & Ordinal \\
\hline 3 & $\begin{array}{l}\text { Faktor } \\
\text { Environme } \\
\quad \text { ntal }\end{array}$ & $\begin{array}{lr}\text { Menyangkut aspek-aspek } \\
\text { lingkungan yang dapat } \\
\text { mempengaruhi } & \text { minat } \\
\text { seseorang } & \text { untuk } \\
\text { berwirausaha. } & \end{array}$ & $\begin{array}{l}\text { 1. Peluang } \\
\text { 2. Pesaing } \\
\text { 3. Modal } \\
\text { 4. Informasi } \\
\text { 5. Kebijakan pemerintah } \\
\text { 6. Kesempatan }\end{array}$ & Ordinal \\
\hline
\end{tabular}

\section{Model Analisis}

\section{a. Analisis Deskriptif}

Merupakan proses pengolahan data yang didapat oleh responden

1. Verifikasi data yaitu memeriksa kembali kuesioner yang telah di isi oleh responden memastikan apakah semua pertanyaan sudah di jawab dengan lengkap oleh responden.

2. Menghitung nilai jawaban. Menghitung Frekuensi dari jawaban yang diberikan responden atas setiap item pertanyaan yang di ajukan, untuk mencari persentase jawaban angket dari responden digunakan rumus: $P$ $=\mathrm{F} / \mathrm{N}$ X 100\%. Dimana: $\mathrm{P}=$ Persentase yang dicari, $\mathrm{F}=$ Frekuensi, $\mathrm{N}$ $=$ Jumlah responden. Untuk mengetahui masing-masing kategori jawaban dari deskriptif variabel, maka dapat dilihat dengan menggunakan rumus sebagai berikut $: \mathrm{TCR}=\mathrm{Rs} / \mathrm{N} \times 100 \%$ Dimana: TCR = Tingkat Capaian Responden, Rs = Rata-rata Skor Jawaban Responden (Rerata), $\mathrm{n}=$ Nilai Skor Maksimum.

\section{b. Analisis Faktor}

Teknik analisis data yang digunakan dalam penelitian ini yaitu teknik analisis faktor. Secara matematis, analisis faktor menyerupai regresi ganda, dimana setiap variabel direpresentasikan sebagai kombinasi linier dari faktor-faktor yang diperoleh dari hasil pengolahan data (Santoso, 2003). Masing-masing faktor dapat diekspresikan dengan persamaan sebagai berikut : 
Dimana,

$$
\mathrm{F}_{1}=\mathrm{W}_{\mathrm{i} 1} \mathrm{X}_{1}+\mathrm{W}_{\mathrm{i} 2} \mathrm{X}_{2}+\mathrm{W}_{\mathrm{i} 3} \mathrm{X}_{3}+\mathrm{W}_{\mathrm{i} 4} \mathrm{X}_{4} \ldots . .+\mathrm{W}_{\mathrm{ik}} \mathrm{X}_{\mathrm{k}}
$$

$\mathrm{F}_{1}$ adalah faktor,

$\mathrm{W}_{\mathrm{i}}$ adalah bobot variabel terhadap faktor,

$\mathrm{X}$ adalah variabel,

$\mathrm{k}$ adalah jumlah variabel

\section{HASIL PENELITIAN DAN PEMBAHASAN}

\section{Hasil Uji Validitas dan Reliabilitas}

Hasil uji validitas dan reliablitas disajikan pada tabel berikut:

Tabel 2. Hasil Uji Validitas

\begin{tabular}{|l|c|c|c|}
\hline \multicolumn{1}{|c|}{$\begin{array}{c}\text { Faktor }- \text { Faktor Penentu Minat Mahasiswa } \\
\text { Untuk Berwirausaha }\end{array}$} & $\begin{array}{c}\text { Correlation } \\
\text { item }\end{array}$ & R-kritis & Keterangan \\
\hline Faktor Personal & & & \\
\hline Kebebasan $\left(\mathrm{V}_{1}\right)$ & 0,820 & 0,30 & Valid \\
\hline Pendapatan $\left(\mathrm{V}_{2}\right)$ & 0,732 & 0,30 & Valid \\
\hline Senang $\left(\mathrm{V}_{3}\right)$ & 0,793 & 0,30 & Valid \\
\hline Kepuasan $\left(\mathrm{V}_{4}\right)$ & 0,572 & 0,30 & Valid \\
\hline Prestise $\left(\mathrm{V}_{5}\right)$ & 0,746 & 0,30 & Valid \\
\hline Kompetensi( $\left.\mathrm{V}_{6}\right)$ & 0,567 & 0,30 & Valid \\
\hline Keyakinan $\left(\mathrm{V}_{7}\right)$ & 0,609 & 0,30 & Valid \\
\hline Optimis $\left(\mathrm{V}_{8}\right)$ & 0,785 & 0,30 & Valid \\
\hline Suka Tantangan $\left(\mathrm{V}_{9}\right)$ & 0,793 & 0,30 & Valid \\
\hline Inovatif $\left(\mathrm{V}_{10}\right)$ & 0,769 & 0,30 & Valid \\
\hline Bertanggung Jawab $\left(\mathrm{V}_{11}\right)$ & 0,779 & 0,30 & Valid \\
\hline Pengalaman $\left(\mathrm{V}_{12}\right)$ & 0,548 & 0,30 & Valid \\
\hline Kreatif $\left(\mathrm{V}_{13}\right)$ & 0,786 & 0,30 & Valid \\
\hline Faktor Sociological & & & \\
\hline Hubungan keluarga $\left(\mathrm{V}_{14}\right)$ & 0,742 & 0,30 & Valid \\
\hline Pekerjaan orang tua $\left(\mathrm{V}_{15}\right)$ & 0,793 & 0,30 & Valid \\
\hline Status Sosial $\left(\mathrm{V}_{16}\right)$ & 0,582 & 0,30 & Valid \\
\hline Tanggung jawab keluarga $\left(\mathrm{V}_{17}\right)$ & 0,796 & 0,30 & Valid \\
\hline Latar belakang kelurga $\left(\mathrm{V}_{18}\right)$ & 0,577 & 0,30 & Valid \\
\hline Faktor Environmental & & & \\
\hline Peluang $\left(\mathrm{V}_{19}\right)$ & 0,587 & 0,30 & Valid \\
\hline Pesaing $\left(\mathrm{V}_{20}\right)$ & 0,699 & 0,30 & Valid \\
\hline Modal $\left(\mathrm{V}_{21}\right)$ & 0,745 & 0,30 & Valid \\
\hline Informasi $\left(\mathrm{V}_{22}\right)$ & 0,693 & 0,30 & Valid \\
\hline Kebijakan pemerintah $\left(\mathrm{V}_{23}\right)$ & 0,679 & 0,30 & Valid \\
\hline Kesempatan $\left(\mathrm{V}_{24}\right)$ & & & Valid \\
\hline Surmer: Hasil Pengolahan & & \\
\hline
\end{tabular}

\section{Sumber: Hasil Pengolahan Data}

Tabel di atas menunjukkan setiap instrumen penelitian adalah valid, untuk digunakan dalam rangka mengukur variabel yang diteliti, karena rhitung $\geq$ dari r-kritis $(0,30)$. 
Tabel 3. . Hasil Uji Reliabilitas

\begin{tabular}{|l|c|c|c|}
\hline \multicolumn{1}{|c|}{$\begin{array}{c}\text { Faktor - Faktor Penentu Minat } \\
\text { Mahasiswa Untuk Berwirausaha }\end{array}$} & $\begin{array}{c}\text { Alpha if } \\
\text { Item }\end{array}$ & $\begin{array}{c}\text { Alpha } \\
\text { kritis }\end{array}$ & Keterangan \\
\hline Faktor Personal & & & \\
\hline Kebebasan $\left(\mathrm{V}_{1}\right)$ & 0,958 & 0,50 & Reliabel \\
\hline Pendapatan $\left(\mathrm{V}_{2}\right)$ & 0,960 & 0,50 & Reliabel \\
\hline Senang $\left(\mathrm{V}_{3}\right)$ & 0,958 & 0,50 & Reliabel \\
\hline Kepuasan $\left(\mathrm{V}_{4}\right)$ & 0,960 & 0,50 & Reliabel \\
\hline Prestise $\left(\mathrm{V}_{5}\right)$ & 0,959 & 0,50 & Reliabel \\
\hline Kompetensi $\left(\mathrm{V}_{6}\right)$ & 0,959 & 0,50 & Reliabel \\
\hline Keyakinan $\left(\mathrm{V}_{7}\right)$ & 0,759 & 0,50 & Reliabel \\
\hline Optimis $\left(\mathrm{V}_{8}\right)$ & 0,859 & 0,50 & Reliabel \\
\hline Suka Tantangan $\left(\mathrm{V}_{9}\right)$ & 0,658 & 0,50 & Reliabel \\
\hline Inovatif $\left(\mathrm{V}_{10}\right)$ & 0,760 & 0,50 & Reliabel \\
\hline Bertanggung Jawab $\left(\mathrm{V}_{11}\right)$ & 0,858 & 0,50 & Reliabel \\
\hline Pengalaman $\left(\mathrm{V}_{12}\right)$ & 0,759 & 0,50 & Reliabel \\
\hline Kreatif $\left(\mathrm{V}_{13}\right)$ & 0,858 & 0,50 & Reliabel \\
\hline Faktor Sociological & & & \\
\hline Hubungan keluarga $\left(\mathrm{V}_{14}\right)$ & 0,959 & 0,50 & Reliabel \\
\hline Pekerjaan orang tua $\left(\mathrm{V}_{15}\right)$ & 0,857 & 0,50 & Reliabel \\
\hline Status Sosial $\left(\mathrm{V}_{16}\right)$ & 0,759 & 0,50 & Reliabel \\
\hline Tanggung jawab keluarga $\left(\mathrm{V}_{17}\right)$ & 0,958 & 0,50 & Reliabel \\
\hline Latar belakang kelurga $\left(\mathrm{V}_{18}\right)$ & 0,859 & 0,50 & Reliabel \\
\hline Faktor Environmental & & & \\
\hline Peluang $\left(\mathrm{V}_{19}\right)$ & 0,660 & 0,50 & Reliabel \\
\hline Pesaing $\left(\mathrm{V}_{20}\right)$ & 0,758 & 0,50 & Reliabel \\
\hline Modal $\left(\mathrm{V}_{21}\right)$ & 0,860 & 0,50 & Reliabel \\
\hline Informasi $\left(\mathrm{V}_{22}\right)$ & 0,859 & 0,50 & Reliabel \\
\hline Kebijakan pemerintah $\left(\mathrm{V}_{23}\right)$ & 0,759 & 0,50 & Reliabel \\
\hline Kesempatan $\left(\mathrm{V}_{24}\right)$ & 0,859 & 0,50 & Reliabel \\
\hline
\end{tabular}

Berdasarkan tabel di atas, ditunjukkan seluruh indikator pengukuran Faktor - Faktor Penentu Minat Mahasiswa Jurusan Manajemen Untuk Berwirausaha, sudah realibel, dan dapat digunakan untuk mengukur variabel yang diteliti, karena nilai alpha lebih besar 0,50 .

\section{Karakteristik Responden}

Dalam mengidentifikasi karakteristik responden, peneliti mengedarkan 160 eksemplar koesioner pada Jurusan Manajemen FE. Unika St. Thomas SU. Koesioner yang kembali 142 eksemplar dan yang sempurna pengisiannya hanya 135 eksemplar koesioner. Namun karena jumlah sampel penelitian telah ditentukan sebelumnya, peneliti hanya meneliti 120 eksemplar koesioner. 


\section{a. Karakteristik Responden Berdasarkan Jenis Kelamin}

Dari 120 responden yang diamati, karakteristik responden berdasarkan jenis kelamin ditunjukkan pada tabel berikut :

Tabel 4. Karakteristik Responden Berdasarkan Jenis Kelamin

\begin{tabular}{|c|c|c|}
\hline Jenis Kelamin & Jumlah ( fi ) & Prosentase ( \% ) \\
\hline Laki-Laki & 85 & 70,8 \\
\hline Perempuan & 35 & 29,1 \\
\hline Jumlah & 120 & 100 \\
\hline
\end{tabular}

Sumber : Diolah dari hasil koesioner

Tabel di atas menunjukkan, mahasiswa yang menyatakan berminat untuk berwirausaha lebih dominan laki-laki dari pada perempuan. Hal ini terjadi karena sampel penelitian tidak sama proporsinya untuk proporsi kaum laki-laki dan perempuan.

\section{b. Karakteristik Responden Berdasarkan Daerah Asal}

Dari 120 responden yang diamati, karakteristik responden berdasarkan daerah asal ditunjukkan pada tabel berikut :

Tabel 5. Karakteristik Responden Berdasarkan Daerah Asal

\begin{tabular}{|c|c|c|}
\hline Daerah Asal & Jumlah ( fi ) & Prosentase ( \% ) \\
\hline Kota Medan & 44 & 36,6 \\
\hline Luar Kota Medan & 76 & 63,3 \\
\hline Jumlah & 120 & 100 \\
\hline
\end{tabular}

Sumber : Diolah dari hasil koesioner

Tabel di atas menunjukkan, asal daerah mahasiswa yang kuliah pada FE. Unika St. Thomas SU lebih dominan berasal dari luar kota Medan dibandingkan dengan dari Kota Medan.

\section{c. Karakteristik Responden Berdasarkan Tingkat Pendidikan Orangtua}

Dari 120 responden yang diamati, karakteristik responden berdasarkan Tingkat Pendidikan Orang Tua ditunjukkan pada tabel berikut:

Tabel 6. Karakteristik Responden Berdasarkan Tingkat Pendidikan Orang Tua

\begin{tabular}{|c|c|c|}
\hline Tingkat Pendidikan & Jumlah ( fi ) & Prosentase (\%) \\
\hline SD & 12 & 10 \\
\hline SMP & 21 & 17,5 \\
\hline SMU & 40 & 33,3 \\
\hline D-3 & 23 & 19,1 \\
\hline S-1 & 24 & 20 \\
\hline Jumlah & 120 & 100 \\
\hline
\end{tabular}

Sumber : Diolah dari hasil koesioner 
Tabel di atas menunjukkan, bahwa tingkat pendidikan orang tua yang diteliti lebih dominan tingkat pendidikan SMU. Tingkat pendidikan orang tua sangat mempengaruhi terhadap keberadaan anaknya untuk penentuan masa depan.

\section{d. Karakteristik Responden Berdasarkan Jenis Pekerjaan Orangtua}

Dari 120 responden yang diamati, karakteristik responden berdasarkan jenis pekerjaan orangtua ditunjukkan pada tabel berikut :

Tabel 7. Karakteristik Responden Berdasarkan Daerah Asal

\begin{tabular}{|c|c|c|}
\hline Jenis Pekerjaan & Jumlah ( fi ) & Prosentase (\%) \\
\hline Bertani & 35 & 29,1 \\
\hline PNS & 24 & 20 \\
\hline Wiraswasta & 32 & 26,6 \\
\hline Pegawai Swasta & 29 & 24,1 \\
\hline Jumlah & 120 & 100 \\
\hline
\end{tabular}

Sumber : Diolah dari hasil koesioner

Tabel di atas menunjukkan, bahwa jenis pekerjaan orangtua yang diteliti lebih dominan sebagai bertani. Jenis Pekerjaan orangtua sangat mempengaruhi terhadap keberadaan anaknya untuk masa yang akan datang.

\section{Analisis Faktor}

\section{a. Analisis KMO and Barllett's Test}

Dari hasil output SPSS versi 17 untuk data 24 pertanyaan yang dijawab oleh 120 responden dengan hasil sebagai berikut:

Tabel 8. KMO and Bartlett's Test

\begin{tabular}{|c|c|c|}
\hline \multicolumn{2}{|c|}{ Kaiser-Meyer-Olkin Measure of Sampling Adequacy. } & 0,858 \\
\hline \multirow[t]{3}{*}{ Bartlett's Test of Sphericity } & Approx. Chi-Square & 721,425 \\
\hline & Df & 231 \\
\hline & Sig. & 0,000 \\
\hline
\end{tabular}

Sumber: Hasil Pengolahan Data

Tabel di atas menunjukkan nilai KMO and Bartlett's Test terlihat angka KMO Measure of Sampling Adeguacy (MSA) adalah 0,858 di atas 0,50 , dengan signifikansi 0,000 , maka variabel dan sampel sudah layak dianalisis lebih lanjut. Dilihat dari angka Chi-Square 721,425 artinya kedua empat variabel Faktor - Faktor Penentu Minat Mahasiswa Jurusan Manajemen Untuk Berwirausaha, dapat diterima pada tingkat signifikansi 0 persen. 


\section{b. Anti Image Correlation}

Tiap variabel dianalisis untuk mengetahui mana yang dapat diproses lebih lanjut dan mana yang harus dikeluarkan. Pada tabel Anti Image Marrices, di bagian Anti Image Correlation terlihat sejumlah angka yang membentuk diagonal yang menandakan besar Measure of Sampling Adeguacy (MSA) masing-masing variabel, seperti yang ditunjukkan pada tabel berikut :

Tabel 9. Anti-image Matrices

\begin{tabular}{|c|c|c|c|c|c|c|c|}
\hline & $\begin{array}{c}\text { Varia } \\
\text { bel }\end{array}$ & V1 & $\mathrm{V} 2$ & V3 & V4 & V5 & V6 \\
\hline Anti-image & V1 & 0,205 & 0,023 & $-0,008$ & 0,053 & $-0,019$ & $-0,003$ \\
\hline \multirow[t]{23}{*}{ Covariance } & V2 & 0,023 & 0,150 & 0,019 & 0,032 & $-0,039$ & $-0,070$ \\
\hline & V3 & $-0,008$ & 0,019 & 0,124 & $-0,011$ & $-0,037$ & 0,046 \\
\hline & V4 & 0,053 & 0,032 & $-0,011$ & 0,313 & 0,000 & 0,015 \\
\hline & V5 & $-0,019$ & $-0,039$ & $-0,037$ & 0,000 & 0,282 & 0,015 \\
\hline & V6 & $-0,003$ & $-0,070$ & 0,046 & 0,015 & 0,015 & 0,202 \\
\hline & V7 & $-0,059$ & 0,069 & $-0,023$ & 0,003 & $-0,068$ & $-0,062$ \\
\hline & V8 & $-0,015$ & $-0,036$ & $-0,049$ & $-0,086$ & 0,066 & $-0,025$ \\
\hline & V9 & 0,043 & 0,015 & 0,039 & 0,023 & 0,015 & 0,039 \\
\hline & V10 & $-0,102$ & $-0,058$ & 0,007 & $-0,072$ & 0,017 & 0,066 \\
\hline & V11 & $-0,044$ & 0,010 & $-0,057$ & $-0,036$ & $-0,004$ & $-0,044$ \\
\hline & V12 & $-0,030$ & 0,062 & $-0,058$ & 0,026 & $-0,052$ & $-0,046$ \\
\hline & V13 & $-0,004$ & 0,023 & 0,001 & $-0,027$ & $-0,028$ & $-0,074$ \\
\hline & V14 & $-0,025$ & $-0,032$ & $-0,002$ & 0,053 & $-0,013$ & 0,044 \\
\hline & V15 & $-0,019$ & $-0,014$ & $-0,046$ & 0,024 & 0,005 & 0,052 \\
\hline & V16 & $-0,020$ & $-0,040$ & $-0,057$ & $-0,079$ & 0,015 & $-0,029$ \\
\hline & V17 & 0,035 & $-0,023$ & 0,030 & $-0,035$ & $-0,003$ & $-0,005$ \\
\hline & V18 & 0,011 & $-0,005$ & 0,002 & 0,000 & $-0,020$ & $-0,056$ \\
\hline & V19 & $-0,046$ & $-0,059$ & 0,030 & $-0,092$ & 0,009 & 0,013 \\
\hline & V20 & $-0,012$ & $-0,028$ & 0,016 & 0,003 & $-0,004$ & 0,049 \\
\hline & V21 & $-0,019$ & $-0,039$ & $-0,037$ & 0,000 & 0,282 & 0,015 \\
\hline & V22 & $-0,003$ & $-0,070$ & 0,046 & 0,015 & 0,015 & 0,202 \\
\hline & V23 & $-0,059$ & 0,069 & $-0,023$ & 0,003 & $-0,068$ & $-0,062$ \\
\hline & V24 & $-0,015$ & $-0,036$ & $-0,049$ & $-0,086$ & 0,066 & $-0,025$ \\
\hline Anti-image & V1 & $0,916(a)$ & 0,129 & $-0,049$ & 0,211 & $-0,081$ & $-0,015$ \\
\hline \multirow[t]{10}{*}{ Correlation } & $\mathrm{V} 2$ & 0,129 & $0,818(a)$ & 0,138 & 0,150 & $-0,187$ & $-0,401$ \\
\hline & V3 & $-0,049$ & 0,138 & 0,873 (a) & $-0,053$ & $-0,197$ & 0,294 \\
\hline & V4 & 0,211 & 0,150 & $-0,053$ & $0,843(a)$ & $-0,002$ & 0,059 \\
\hline & V5 & $-0,081$ & $-0,187$ & $-0,197$ & $-0,002$ & $0,942(a)$ & 0,062 \\
\hline & V6 & $-0,015$ & $-0,401$ & 0,294 & 0,059 & 0,062 & $0,826(a)$ \\
\hline & V7 & $-0,311$ & 0,423 & $-0,157$ & 0,011 & $-0,303$ & $-0,329$ \\
\hline & V8 & $-0,079$ & $-0,211$ & $-0,320$ & $-0,353$ & 0,287 & $-0,129$ \\
\hline & V9 & 0,195 & 0,079 & 0,224 & 0,084 & 0,059 & 0,177 \\
\hline & V10 & $-0,439$ & $-0,290$ & 0,041 & $-0,249$ & 0,061 & 0,285 \\
\hline & V11 & $-0,296$ & 0,078 & $-0,496$ & $-0,198$ & $-0,025$ & $-0,298$ \\
\hline
\end{tabular}




\begin{tabular}{|l|r|r|r|r|r|r|} 
V12 & $-0,170$ & 0,410 & $-0,422$ & 0,119 & $-0,250$ & $-0,259$ \\
V13 & $-0,021$ & 0,145 & 0,007 & $-0,117$ & $-0,126$ & $-0,392$ \\
V14 & $-0,093$ & $-0,139$ & $-0,012$ & 0,160 & $-0,041$ & 0,164 \\
V15 & $-0,085$ & $-0,076$ & $-0,268$ & 0,088 & 0,018 & 0,238 \\
V16 & $-0,101$ & $-0,230$ & $-0,361$ & $-0,318$ & 0,063 & $-0,147$ \\
V17 & 0,200 & $-0,152$ & 0,221 & $-0,163$ & $-0,014$ & $-0,026$ \\
V18 & 0,056 & $-0,029$ & 0,013 & $-0,002$ & $-0,092$ & $-0,300$ \\
V19 & $-0,219$ & $-0,324$ & 0,181 & $-0,351$ & 0,034 & 0,062 \\
V20 & $-0,066$ & $-0,173$ & 0,107 & 0,012 & $-0,020$ & 0,264 \\
V21 & $-0,439$ & $-0,290$ & 0,041 & $-0,249$ & 0,061 & 0,285 \\
V22 & $-0,296$ & 0,078 & $-0,496$ & $-0,198$ & $-0,025$ & $-0,298$ \\
V23 & $-0,170$ & 0,410 & $-0,422$ & 0,119 & $-0,250$ & $-0,259$ \\
V24 & $-0,021$ & 0,145 & 0,007 & $-0,117$ & $-0,126$ & $-0,392$ \\
\hline
\end{tabular}

Anti-image Matrices (Lanjutan)

\begin{tabular}{|c|r|r|r|r|r|r|r|r|}
\hline Variabel & \multicolumn{1}{|c|}{ V7 } & \multicolumn{1}{|c|}{ V8 } & \multicolumn{1}{c|}{ V9 } & \multicolumn{1}{c|}{ V10 } & \multicolumn{1}{c|}{ V11 } & \multicolumn{1}{c|}{ V12 } & \multicolumn{1}{c|}{ V13 } & \multicolumn{1}{c|}{ V14 } \\
\hline V1 & $-0,059$ & $-0,015$ & 0,043 & $-0,102$ & $-0,044$ & $-0,030$ & $-0,004$ & $-0,025$ \\
V2 & 0,069 & $-0,036$ & 0,015 & $-0,058$ & 0,010 & 0,062 & 0,023 & $-0,032$ \\
V3 & $-0,023$ & $-0,049$ & 0,039 & 0,007 & $-0,057$ & $-0,058$ & 0,001 & $-0,002$ \\
V4 & 0,003 & $-0,086$ & 0,023 & $-0,072$ & $-0,036$ & 0,026 & $-0,027$ & 0,053 \\
V5 & $-0,068$ & 0,066 & 0,015 & 0,017 & $-0,004$ & $-0,052$ & $-0,028$ & $-0,013$ \\
V6 & $-0,062$ & $-0,025$ & 0,039 & 0,066 & $-0,044$ & $-0,046$ & $-0,074$ & 0,044 \\
V7 & 0,178 & 0,018 & $-0,073$ & 0,030 & 0,063 & 0,085 & 0,000 & $-0,005$ \\
V8 & 0,018 & 0,190 & 0,015 & 0,006 & 0,034 & $-0,010$ & 0,005 & $-0,063$ \\
V9 & $-0,073$ & 0,015 & 0,241 & $-0,088$ & $-0,063$ & $-0,034$ & 0,004 & $-0,033$ \\
V10 & 0,030 & 0,006 & $-0,088$ & 0,266 & 0,036 & $-0,026$ & $-0,091$ & 0,037 \\
V11 & 0,063 & 0,034 & $-0,063$ & 0,036 & 0,108 & 0,073 & $-0,021$ & $-0,025$ \\
V12 & 0,085 & $-0,010$ & $-0,034$ & $-0,026$ & 0,073 & 0,154 & 0,013 & $-0,019$ \\
V13 & 0,000 & 0,005 & 0,004 & $-0,091$ & $-0,021$ & 0,013 & 0,175 & $-0,065$ \\
V14 & $-0,005$ & $-0,063$ & $-0,033$ & 0,037 & $-0,025$ & $-0,019$ & $-0,065$ & 0,352 \\
V15 & $-0,011$ & 0,013 & 0,010 & 0,036 & 0,013 & 0,030 & $-0,078$ & 0,082 \\
V16 & 0,016 & 0,091 & $-0,073$ & 0,025 & 0,065 & 0,008 & 0,035 & $-0,090$ \\
V17 & $-0,069$ & $-0,049$ & $-0,017$ & 0,020 & $-0,031$ & $-0,072$ & $-0,019$ & 0,012 \\
V18 & $-0,003$ & $-0,019$ & $-0,036$ & $-0,012$ & $-0,018$ & $-0,029$ & 0,005 & 0,001 \\
V19 & $-0,032$ & $-0,014$ & $-0,027$ & 0,008 & $-0,002$ & $-0,024$ & 0,039 & $-0,033$ \\
V20 & $-0,039$ & $-0,072$ & $-0,008$ & $-0,006$ & $-0,011$ & 0,006 & $-0,011$ & 0,017 \\
V1 & $-0,311$ & $-0,079$ & 0,195 & $-0,439$ & $-0,296$ & $-0,170$ & $-0,021$ & $-0,093$ \\
V2 & 0,423 & $-0,211$ & 0,079 & $-0,290$ & 0,078 & 0,410 & 0,145 & $-0,139$ \\
V3 & $-0,157$ & $-0,320$ & 0,224 & 0,041 & $-0,496$ & $-0,422$ & 0,007 & $-0,012$ \\
V4 & 0,011 & $-0,353$ & 0,084 & $-0,249$ & $-0,198$ & 0,119 & $-0,117$ & 0,160 \\
V5 & $-0,303$ & 0,287 & 0,059 & 0,061 & $-0,025$ & $-0,250$ & $-0,126$ & $-0,041$ \\
V6 & $-0,329$ & $-0,129$ & 0,177 & 0,285 & $-0,298$ & $-0,259$ & $-0,392$ & 0,164 \\
V7 & $0,782(\mathrm{a})$ & 0,098 & $-0,353$ & 0,139 & 0,454 & 0,514 & $-0,002$ & $-0,019$ \\
V8 & 0,098 & $0,826(\mathrm{a})$ & 0,071 & 0,028 & 0,239 & $-0,057$ & 0,029 & $-0,244$ \\
V9 & $-0,353$ & 0,071 & $0,873(\mathrm{a})$ & $-0,349$ & $-0,393$ & $-0,179$ & 0,021 & $-0,113$
\end{tabular}




\begin{tabular}{l|r|r|r|r|r|r|r|r|} 
V10 & 0,139 & 0,028 & $-0,349$ & $0,831(\mathrm{a})$ & 0,215 & $-0,131$ & $-0,422$ & 0,120 \\
V11 & 0,454 & 0,239 & $-0,393$ & 0,215 & $0,782(\mathrm{a})$ & 0,569 & $-0,151$ & $-0,128$ \\
V12 & 0,514 & $-0,057$ & $-0,179$ & $-0,131$ & 0,569 & $0,719(\mathrm{a})$ & 0,079 & $-0,080$ \\
V13 & $-0,002$ & 0,029 & 0,021 & $-0,422$ & $-0,151$ & 0,079 & $0,908(\mathrm{a})$ & $-0,260$ \\
V14 & $-0,019$ & $-0,244$ & $-0,113$ & 0,120 & $-0,128$ & $-0,080$ & $-0,260$ & $0,911(\mathrm{a})$ \\
V15 & $-0,052$ & 0,060 & 0,042 & 0,142 & 0,080 & 0,158 & $-0,382$ & 0,284 \\
V16 & 0,083 & 0,471 & $-0,332$ & 0,109 & 0,444 & 0,043 & 0,189 & $-0,340$ \\
V17 & $-0,424$ & $-0,294$ & $-0,087$ & 0,099 & $-0,242$ & $-0,476$ & $-0,119$ & 0,050 \\
V18 & $-0,018$ & $-0,107$ & $-0,173$ & $-0,054$ & $-0,129$ & $-0,180$ & 0,031 & 0,005 \\
V19 & $-0,162$ & $-0,070$ & $-0,115$ & 0,034 & $-0,014$ & $-0,131$ & 0,201 & $-0,119$ \\
V20 & $-0,221$ & $-0,394$ & $-0,038$ & $-0,026$ & $-0,082$ & 0,038 & $-0,061$ & 0,069 \\
V21 & 0,083 & 0,471 & $-0,332$ & 0,109 & 0,444 & 0,043 & 0,189 & $-0,340$ \\
V22 & $-0,424$ & $-0,294$ & $-0,087$ & 0,099 & $-0,242$ & $-0,476$ & $-0,119$ & 0,050 \\
V23 & $-0,018$ & $-0,107$ & $-0,173$ & $-0,054$ & $-0,129$ & $-0,180$ & 0,031 & 0,005 \\
V24 & $-0,052$ & 0,060 & 0,042 & 0,142 & 0,080 & 0,158 & $-0,382$ & 0,284 \\
\hline
\end{tabular}

Anti-image Matrices (Lanjutan)

\begin{tabular}{|c|r|r|r|r|r|r|r|r|}
\hline Variabel & \multicolumn{1}{|c|}{ V15 } & \multicolumn{1}{c|}{ V16 } & \multicolumn{1}{c|}{ V17 } & \multicolumn{1}{c|}{ V18 } & \multicolumn{1}{c|}{ V19 } & \multicolumn{1}{c|}{ V20 } & \multicolumn{1}{c|}{ V21 } & \multicolumn{1}{c|}{ V22 } \\
\hline V1 & $-0,019$ & $-0,020$ & 0,035 & 0,011 & $-0,046$ & $-0,012$ & $-0,001$ & 0,023 \\
V2 & $-0,014$ & $-0,040$ & $-0,023$ & $-0,005$ & $-0,059$ & $-0,028$ & $-0,073$ & $-0,037$ \\
V3 & $-0,046$ & $-0,057$ & 0,030 & 0,002 & 0,030 & 0,016 & $-0,015$ & $-0,012$ \\
V4 & 0,024 & $-0,079$ & $-0,035$ & 0,000 & $-0,092$ & 0,003 & $-0,045$ & 0,093 \\
V5 & 0,005 & 0,015 & $-0,003$ & $-0,020$ & 0,009 & $-0,004$ & 0,034 & $-0,008$ \\
V6 & 0,052 & $-0,029$ & $-0,005$ & $-0,056$ & 0,013 & 0,049 & 0,022 & 0,002 \\
V7 & $-0,011$ & 0,016 & $-0,069$ & $-0,003$ & $-0,032$ & $-0,039$ & $-0,044$ & $-0,035$ \\
V8 & 0,013 & 0,091 & $-0,049$ & $-0,019$ & $-0,014$ & $-0,072$ & 0,080 & $-0,047$ \\
V9 & 0,010 & $-0,073$ & $-0,017$ & $-0,036$ & $-0,027$ & $-0,008$ & 0,066 & 0,005 \\
V10 & 0,036 & 0,025 & 0,020 & $-0,012$ & 0,008 & $-0,006$ & $-0,017$ & 0,003 \\
V11 & 0,013 & 0,065 & $-0,031$ & $-0,018$ & $-0,002$ & $-0,011$ & $-0,040$ & $-0,059$ \\
V12 & 0,030 & 0,008 & $-0,072$ & $-0,029$ & $-0,024$ & 0,006 & $-0,077$ & $-0,030$ \\
V13 & $-0,078$ & 0,035 & $-0,019$ & 0,005 & 0,039 & $-0,011$ & 0,019 & $-0,013$ \\
V14 & 0,082 & $-0,090$ & 0,012 & 0,001 & $-0,033$ & 0,017 & $-0,026$ & 0,057 \\
V15 & $-0,076$ & $-0,230$ & $-0,152$ & $-0,029$ & $-0,324$ & $-0,173$ & $-0,029$ & 0,013 \\
V16 & $-0,268$ & $-0,361$ & 0,221 & 0,013 & 0,181 & 0,107 & $-0,006$ & $-0,062$ \\
V17 & 0,088 & $-0,318$ & $-0,163$ & $-0,002$ & $-0,351$ & 0,012 & $-0,387$ & 0,016 \\
V18 & 0,018 & 0,063 & $-0,014$ & $-0,092$ & 0,034 & $-0,020$ & $-0,086$ & 0,039 \\
V19 & 0,238 & $-0,147$ & $-0,026$ & $-0,300$ & 0,062 & 0,264 & $-0,168$ & $-0,038$ \\
V20 & $-0,052$ & 0,083 & $-0,424$ & $-0,018$ & $-0,162$ & $-0,221$ & 0,132 & $-0,014$ \\
V21 & 0,060 & 0,471 & $-0,294$ & $-0,107$ & $-0,070$ & $-0,394$ & 0,100 & 0,057 \\
V22 & 0,238 & $-0,026$ & $-0,054$ & 0,013 & $-0,086$ & $-0,040$ & 0,013 & 0,013 \\
V23 & $-0,026$ & 0,199 & $-0,012$ & $-0,047$ & 0,022 & $-0,016$ & 0,038 & $-0,062$ \\
V24 & $-0,054$ & $-0,012$ & 0,149 & 0,036 & 0,010 & 0,037 & $-0,029$ & 0,016 \\
V1 & $-0,085$ & $-0,101$ & 0,200 & 0,056 & $-0,219$ & $-0,066$ & $-0,006$ & 0,127 \\
V2 & $-0,076$ & $-0,230$ & $-0,152$ & $-0,029$ & $-0,324$ & $-0,173$ & $-0,387$ & $-0,235$ \\
V3 & $-0,268$ & $-0,361$ & 0,221 & 0,013 & 0,181 & 0,107 & $-0,086$ & $-0,085$ \\
V4 & 0,088 & $-0,318$ & $-0,163$ & $-0,002$ & $-0,351$ & 0,012 & $-0,168$ & 0,409
\end{tabular}




\begin{tabular}{|c|c|c|c|c|c|c|c|c|}
\hline V5 & 0,018 & 0,063 & $-0,014$ & $-0,092$ & 0,034 & $-0,020$ & 0,132 & $-0,039$ \\
\hline V6 & 0,238 & $-0,147$ & $-0,026$ & $-0,300$ & 0,062 & 0,264 & 0,100 & 0,014 \\
\hline V7 & $-0,052$ & 0,083 & $-0,424$ & $-0,018$ & $-0,162$ & $-0,221$ & $-0,215$ & $-0,204$ \\
\hline V8 & 0,060 & 0,471 & $-0,294$ & $-0,107$ & $-0,070$ & $-0,394$ & 0,381 & $-0,265$ \\
\hline V9 & 0,042 & $-0,332$ & $-0,087$ & $-0,173$ & $-0,115$ & $-0,038$ & 0,279 & 0,025 \\
\hline V10 & 0,142 & 0,109 & 0,099 & $-0,054$ & 0,034 & $-0,026$ & $-0,066$ & 0,012 \\
\hline V11 & 0,080 & 0,444 & $-0,242$ & $-0,129$ & $-0,014$ & $-0,082$ & $-0,251$ & $-0,444$ \\
\hline V12 & 0,158 & 0,043 & $-0,476$ & $-0,180$ & $-0,131$ & 0,038 & $-0,404$ & $-0,189$ \\
\hline V13 & $-0,382$ & 0,189 & $-0,119$ & 0,031 & 0,201 & $-0,061$ & 0,092 & $-0,074$ \\
\hline V14 & 0,284 & $-0,340$ & 0,050 & 0,005 & $-0,119$ & 0,069 & $-0,089$ & 0,236 \\
\hline V15 & $\begin{array}{r}0,891( \\
\text { a) }\end{array}$ & $-0,119$ & $-0,285$ & 0,062 & $-0,375$ & $-0,195$ & 0,056 & 0,065 \\
\hline V16 & $-0,119$ & $0,798(a)$ & $-0,071$ & $-0,252$ & 0,107 & $-0,088$ & 0,174 & $-0,342$ \\
\hline V17 & $-0,285$ & $-0,071$ & $0,876(a)$ & 0,225 & 0,054 & 0,231 & $-0,158$ & 0,102 \\
\hline V18 & 0,062 & $-0,252$ & 0,225 & $0,923(\mathrm{a})$ & $-0,139$ & $-0,446$ & 0,034 & 0,226 \\
\hline V19 & $-0,375$ & 0,107 & 0,054 & $-0,139$ & $0,865(a)$ & 0,478 & $-0,045$ & $-0,199$ \\
\hline V20 & $-0,195$ & $-0,088$ & 0,231 & $-0,446$ & 0,478 & 0,860(a & $-0,262$ & $-0,080$ \\
\hline $\mathrm{V} 21$ & 0,142 & 0,109 & 0,099 & $-0,054$ & 0,034 & $-0,026$ & 0,876 (a) & 0,012 \\
\hline V22 & 0,080 & 0,444 & $-0,242$ & $-0,129$ & $-0,014$ & $-0,082$ & $-0,251$ & $-0,444$ \\
\hline V23 & 0,158 & 0,043 & $-0,476$ & $-0,180$ & $-0,131$ & 0,038 & $-0,404$ & $-0,189$ \\
\hline V24 & $-0,382$ & 0,189 & $-0,119$ & 0,031 & 0,201 & $-0,061$ & 0,092 & $-0,074$ \\
\hline
\end{tabular}

Berdasarkan tabel di atas, ditunjukkan dari 24 variabel, kemudian dianalisis pada anti image correlation menunjukkan kriteria MSA di atas 0,5 yang berarti variabel masih bisa diprediksi untuk dianalisis lebih lanjut. Dari hasil pengujian tersebut diketahui bahwa semua variabel mempunyai korelasi cukup tinggi dengan variabel lain, sehingga analisis layak untuk dilanjutkan dengan mengikutkan 24 variabel yang mempengaruhi faktor faktor penentu minat mahasiswa jurusan manajemen untuk berwirausaha.

\section{c. Communilaties}

Communalities pada dasarnya adalah jumlah varians (bisa dalam persentase) dari suatu variabel mula-mula yang bisa dijelaskan oleh faktor yang ada. Semua variabel dijelaskan oleh faktor yang terbentuk dengan ketentuan semakin besar communalities maka semakin erat hubungan variabel yang bersangkutan dengan faktor yang terbentuk. Hasil communalities yang diperoleh pada tabel berikut : 
Tabel 10. Cummunalities

\begin{tabular}{|c|c|c|}
\hline $\begin{array}{l}\text { Faktor - Faktor Penentu Minat Mahasiswa Jurusan } \\
\text { Manajemen Untuk Berwirausaha }\end{array}$ & Initial & Extraction \\
\hline \multicolumn{3}{|l|}{ Faktor Personal } \\
\hline Kebebasan $\left(\mathrm{V}_{1}\right)$ & 1,000 & 0,816 \\
\hline Pendapatan $\left(\mathrm{V}_{2}\right)$ & 1,000 & 0,744 \\
\hline Senang $\left(V_{3}\right)$ & 1,000 & 0,697 \\
\hline Kepuasan $\left(\mathrm{V}_{4}\right)$ & 1,000 & 0,761 \\
\hline Prestise $\left(V_{5}\right)$ & 1,000 & 0,711 \\
\hline Kompetensi $\left(\mathrm{V}_{6}\right)$ & 1,000 & 0,777 \\
\hline Keyakinan $\left(\mathrm{V}_{7}\right)$ & 1,000 & 0,709 \\
\hline Optimis $\left(\mathrm{V}_{8}\right)$ & 1,000 & 0,654 \\
\hline Suka Tantangan( $\left(\mathrm{V}_{9}\right)$ & 1,000 & 0,664 \\
\hline Inovatif $\left(\mathrm{V}_{10}\right)$ & 1,000 & 0,762 \\
\hline Bertanggung Jawab $\left(\mathrm{V}_{11}\right)$ & 1,000 & 0,722 \\
\hline Pengalaman $\left(\mathrm{V}_{12}\right)$ & 1,000 & 0,714 \\
\hline Kreatif $\left(V_{13}\right)$ & 1,000 & 0,629 \\
\hline \multicolumn{3}{|l|}{ Faktor Sociological } \\
\hline Hubungan keluarga $\left(\mathrm{V}_{14}\right)$ & 1,000 & 0,674 \\
\hline Pekerjaan orang tua $\left(\mathrm{V}_{15}\right)$ & 1,000 & 0,829 \\
\hline Status Sosial $\left(\mathrm{V}_{16}\right)$ & 1,000 & 0,830 \\
\hline Tanggung jawab keluarga $\left(\mathrm{V}_{17}\right)$ & 1,000 & 0,665 \\
\hline Latar belakang kelurga $\left(\mathrm{V}_{18}\right)$ & 1,000 & 0,712 \\
\hline \multicolumn{3}{|l|}{ Faktor Environmental } \\
\hline Peluang $\left(\mathrm{V}_{19}\right)$ & 1,000 & 0,762 \\
\hline Pesaing $\left(\mathrm{V}_{20}\right)$ & 1,000 & 0,722 \\
\hline Modal $\left(\mathrm{V}_{21}\right)$ & 1,000 & 0,714 \\
\hline Informasi $\left(\mathrm{V}_{22}\right)$ & 1,000 & 0,761 \\
\hline Kebijakan pemerintah $\left(\mathrm{V}_{23}\right)$ & 1,000 & 0,711 \\
\hline Kesempatan $\left(\mathrm{V}_{24}\right)$ & 1,000 & 0,777 \\
\hline
\end{tabular}

Extraction Method: Principal Component Analysis.

Sumber: Hasil Pengolahan Data

Arti communalities sebagai berikut:

1. Variabel Kebebasan $\left(\mathrm{V}_{1}\right)$, angka 0,816 artinya Kebebasan dapat menjelaskan $81,6 \%$ varians yang terbentuk.

2. Variabel Pendapatan $\left(\mathrm{V}_{2}\right)$ angka 0,744 artinya Pendapatan dapat menjelaskan $74,4 \%$ varians yang terbentuk . 
3. Variabel Perasaan Senang $\left(\mathrm{V}_{3}\right)$ angka 0,697 artinya Perasaan Senang dapat menjelaskan $69,7 \%$ varians yang terbentuk .

4. Variabel Kepuasan $\left(\mathrm{V}_{4}\right)$ angka 0,761 artinya Kepuasan dapat menjelaskan $76,1 \%$ varians yang terbentuk .

5. Variabel Prestise $\left(\mathrm{V}_{5}\right)$ angka 0,711 artinya Prestise dapat menjelaskan $71,1 \%$ varians yang terbentuk . Demikian juga penjelasan berikutnya sampai factor ke 24 .

\section{d. Component Matrix}

Factor loading yaitu besarnya korelasi antara masing-masing variabel dengan faktor 1 , faktor 2 , faktor 3 dan faktor 4 . Penentuan variabel yang masing-masing faktor dilakukan dengan memperbandingkan besaran korelasi setiap baris. Angka korelasi dibawah 0,50 menunjukkan indikasi korelasi yang lemah sedangkan di atas 0,50 berindikasi kuat korelasinya. Component matrix disajikan pada berikut :

Tabel 11. Component Matrix

\begin{tabular}{|l|r|r|r|r|}
\hline Faktor - Faktor Penentu Minat Mahasiswa & \multicolumn{4}{|c|}{ Component } \\
\cline { 3 - 5 } Jurusan Manajemen Untuk Berwirausaha & \multicolumn{1}{|c|}{1} & \multicolumn{1}{c|}{2} & \multicolumn{1}{c|}{3} & \multicolumn{1}{c|}{4} \\
\hline Kebebasan $\left(\mathrm{V}_{1}\right)$ & 0,819 & 0,228 & 0,077 & $-0,004$ \\
\hline Pendapatan $\left(\mathrm{V}_{2}\right)$ & 0,700 & $-0,566$ & $-0,024$ & 0,072 \\
\hline Senang $\left(\mathrm{V}_{3}\right)$ & 0,822 & 0,253 & 0,051 & $-0,027$ \\
\hline Kepuasan $\left(\mathrm{V}_{4}\right)$ & 0,636 & $-0,059$ & $-0,283$ & 0,458 \\
\hline Prestise $\left(\mathrm{V}_{5}\right)$ & 0,759 & 0,372 & 0,068 & $-0,204$ \\
\hline Kompetensi $\left(\mathrm{V}_{6}\right)$ & 0,687 & $-0,388$ & $-0,166$ & $-0,246$ \\
\hline Keyakinan $\left(\mathrm{V}_{7}\right)$ & 0,697 & 0,361 & $-0,115$ & $-0,384$ \\
\hline Optimis $\left(\mathrm{V}_{8}\right)$ & 0,730 & $-0,340$ & $-0,128$ & 0,209 \\
\hline Suka Tantangan( $\left.\mathrm{V}_{9}\right)$ & 0,727 & 0,130 & 0,308 & $-0,119$ \\
\hline Inovatif $\left(\mathrm{V}_{10}\right)$ & 0,630 & 0,032 & 0,231 & 0,461 \\
\hline Bertanggung Jawab $\left(\mathrm{V}_{11}\right)$ & 0,781 & $-0,243$ & $-0,139$ & $-0,270$ \\
\hline Pengalaman( $\left.\mathrm{V}_{12}\right)$ & 0,625 & 0,422 & 0,060 & 0,387 \\
\hline Kreatif $\left(\mathrm{V}_{13}\right)$ & 0,823 & $-0,048$ & $-0,142$ & $-0,121$ \\
\hline Hubungan keluarga $\left(\mathrm{V}_{14}\right)$ & 0,723 & $-0,065$ & 0,289 & 0,139 \\
\hline Pekerjaan orang tua $\left(\mathrm{V}_{15}\right)$ & 0,739 & 0,210 & $-0,301$ & $-0,165$ \\
\hline Status Sosial $\left(\mathrm{V}_{16}\right)$ & 0,679 & 0,095 & 0,449 & $-0,040$ \\
\hline Tanggung jawab keluarga $\left(\mathrm{V}_{17}\right)$ & 0,786 & 0,165 & $-0,426$ & 0,042 \\
\hline Latar belakang kelurga $\left(\mathrm{V}_{18}\right)$ & 0,802 & $-0,195$ & 0,386 & 0,015 \\
\hline Peluang $\left(\mathrm{V}_{19}\right)$ & 0,721 & $-0,012$ & $-0,348$ & 0,153 \\
\hline
\end{tabular}




\begin{tabular}{|l|r|r|r|r|}
\hline Pesaing $\left(\mathrm{V}_{20}\right)$ & 0,727 & $-0,221$ & 0,361 & $-0,068$ \\
\hline Modal $\left(\mathrm{V}_{21}\right)$ & 0,727 & 0,130 & 0,308 & $-0,119$ \\
\hline Informasi $\left(\mathrm{V}_{22}\right)$ & 0,630 & 0,032 & 0,231 & 0,461 \\
\hline Kebijakan pemerintah $\left(\mathrm{V}_{23}\right)$ & 0,781 & $-0,243$ & $-0,139$ & $-0,270$ \\
\hline Kesempatan $\left(\mathrm{V}_{24}\right)$ & 0,679 & 0,095 & 0,449 & $-0,040$ \\
\hline
\end{tabular}

Extraction Method: Principal Component Analysis. a 4 components extracted.

Sumber: Hasil Pengolahan Data

Berdasarkan Tabel di atas, uraian arti component matrix sebagai berikut:

1) Variabel Kebebasan $\left(\mathrm{V}_{1}\right)$ berkorelasi dengan faktor 1 sebesar 0,819, maka dikelompokkan menjadi faktor 1.

2) Variabel Pendapatan $\left(V_{2}\right)$ berkorelasi dengan faktor 1 sebesar 0,700 maka dikelompokkan menjadi faktor 1.

3) Variabel Senang $\left(V_{3}\right)$ berkorelasi dengan faktor 1 sebesar 0,822 maka dikelompokkan menjadi faktor 1 .

4) Variabel Kepuasan $\left(\mathrm{V}_{4}\right)$ berkorelasi dengan faktor 1 sebesar 0,636 maka dikelompokkan menjadi faktor 1 .

5) Variabel Prestise $\left(V_{5}\right)$, berkorelasi dengan faktor 1 sebesar 0,759 maka dikelompokkan menjadi faktor 1. Demikian juga penjelasan berikutnya sampai faktor yang ke 24

\section{e. Rotated Component Matrix}

Dari 24 variabel telah terbentuk, namun perlu dilakukan rotasi untuk memperjelas variabel-variabel mana yang masuk ke dalam tiap-tiap faktor. Ada kemungkinan faktor loading yang berubah setelah mengalami rotasi menjadi lebih kecil atau lebih besar.

Tabel 12. Rotated Component Matrix

\begin{tabular}{|l|c|c|c|c|}
\hline Faktor - Faktor Penentu Minat Mahasiswa & \multicolumn{4}{|c|}{ Component } \\
\cline { 2 - 5 } Jurusan Manajemen Untuk Berwirausaha & 1 & 2 & 3 & \multicolumn{1}{c|}{4} \\
\hline Kebebasan $\left(\mathrm{V}_{1}\right)$ & 0,551 & 0,401 & 0,204 & 0,363 \\
\hline Pendapatan $\left(\mathrm{V}_{2}\right)$ & 0,008 & 0,325 & 0,780 & 0,318 \\
\hline Senang $\left(\mathrm{V}_{3}\right)$ & 0,588 & 0,480 & 0,198 & 0,359 \\
\hline Kepuasan $\left(\mathrm{V}_{4}\right)$ & 0,151 & 0,130 & 0,302 & 0,752 \\
\hline Prestise $\left(\mathrm{V}_{5}\right)$ & 0,712 & 0,450 & 0,116 & 0,195 \\
\hline Kompetensi $\left(\mathrm{V}_{6}\right)$ & 0,315 & 0,177 & 0,751 & 0,128 \\
\hline Keyakinan $\left(\mathrm{V}_{7}\right)$ & 0,821 & 0,246 & 0,185 & 0,488 \\
\hline Optimis $\left(\mathrm{V}_{8}\right)$ & 0,118 & 0,275 & 0,603 & 0,405 \\
\hline Suka Tantangan $\left(\mathrm{V}_{9}\right)$ & 0,434 & 0,634 & 0,215 & 0,133 \\
\hline
\end{tabular}




\begin{tabular}{|l|r|r|r|r|}
\hline Inovatif $\left(\mathrm{V}_{10}\right)$ & 0,045 & 0,567 & 0,107 & 0,574 \\
\hline Bertanggung Jawab $\left(\mathrm{V}_{11}\right)$ & 0,456 & 0,253 & 0,689 & 0,158 \\
\hline Pengalaman $\left(\mathrm{V}_{12}\right)$ & 0,364 & 0,430 & $-0,147$ & 0,721 \\
\hline Kreatif $\left(\mathrm{V}_{13}\right)$ & 0,517 & 0,294 & 0,518 & 0,320 \\
\hline Hubungan keluarga $\left(\mathrm{V}_{14}\right)$ & 0,188 & 0,630 & 0,303 & 0,323 \\
\hline Pekerjaan orang tua $\left(\mathrm{V}_{15}\right)$ & 0,696 & 0,124 & 0,309 & 0,335 \\
\hline Status Sosial $\left(\mathrm{V}_{16}\right)$ & 0,304 & 0,735 & 0,165 & 0,119 \\
\hline Tanggung jawab keluarga $\left(\mathrm{V}_{17}\right)$ & 0,624 & 0,059 & 0,342 & 0,364 \\
\hline Latar belakang kelurga $\left(\mathrm{V}_{18}\right)$ & 0,188 & 0,737 & 0,456 & 0,209 \\
\hline Peluang $\left(\mathrm{V}_{19}\right)$ & 0,403 & 0,094 & 0,404 & 0,575 \\
\hline Pesaing $\left(\mathrm{V}_{20}\right)$ & 0,184 & 0,668 & 0,468 & 0,115 \\
\hline Modal $\left(\mathrm{V}_{21}\right)$ & 0,456 & 0,253 & 0,682 & 0,158 \\
\hline Informasi $\left(\mathrm{V}_{22}\right)$ & 0,364 & 0,430 & $-0,147$ & 0,619 \\
\hline Kebijakan pemerintah $\left(\mathrm{V}_{23}\right)$ & 0,517 & 0,294 & 0,508 & 0,320 \\
\hline Kesempatan $\left(\mathrm{V}_{24}\right)$ & 0,188 & 0,630 & 0,303 & 0,323 \\
\hline
\end{tabular}

Extraction Method: Principal Component Analysis. Rotation Method: Varimax with Kaiser Normalization. a Rotation converged in 10 iterations.

Hasil analisisnya adalah sebagai berikut:

1. Variabel Kebebasan $\left(\mathrm{V}_{1}\right)$ berkorelasi dengan faktor 1 sebelum rotasi 0,819 , setelah rotasi menjadi 0,551, maka dikelompokkan menjadi faktor 1 .

2. Variabel Pendapatan $\left(\mathrm{V}_{2}\right)$ berkorelasi dengan faktor 3 sebelum rotasi $-0,024$, setelah rotasi menjadi 0,780 maka dikelompokkan menjadi faktor 3 .

3. Variabel Senang $\left(\mathrm{V}_{3}\right)$ berkorelasi dengan faktor 1 sebelum rotasi 0,822, setelah rotasi menjadi 0,588 maka dikelompokkan menjadi faktor 1 .

4. Variabel Kepuasan $\left(\mathrm{V}_{4}\right)$ berkorelasi dengan faktor 4 sebelum rotasi 0,458, setelah rotasi menjadi 0,752 maka dikelompokkan menjadi faktor 4 .

5. Variabel Prestise $\left(\mathrm{V}_{5}\right)$ berkorelasi dengan faktor 1 sebelum rotasi 0,759 setelah rotasi menjadi 0,712 maka dikelompokkan menjadi faktor 1 . Demikian juga penjelasan berikutnya sampai faktor yang ke 24

\section{f. Component Transformation Matrix}

Tabel 13. Component Tranformation Matrix

\begin{tabular}{|c|c|c|c|c|}
\hline Component & 1 & 2 & 3 & 4 \\
\hline 1 & 0,534 & 0,320 & 0,491 & 0,451 \\
2 & 0,393 & 0,593 & $-0,796$ & 0,114 \\
3 & $-0,302$ & 0,451 & 0,848 & $-0,369$ \\
4 & $-0,521$ & 0,091 & $-0,268$ & 0,805 \\
\hline
\end{tabular}

Extraction Method: Principal Component Analysis. Rotation Method: Varimax with Kaiser Normalization.

Sumber: Hasil Pengolahan Data 
Berdasarkan tabel di atas, terlihat bahwa pada diagonal faktor (component) 1 yang berada di atas angka 0,50 (0,534). Untuk component 2 angka di atas 0,50 (0,593). Untuk component 3 angka di atas $0,50(0,848)$. Untuk component 4 angka di atas $0,50(0,805)$. Hal ini yang menunjukkan bahwa ke 4 faktor (component) yang terbentuk sudah tepat, karena mempunyai korelasi tinggi.

\section{g. Faktor yang Paling Dominan Sebagai Penentu Minat Mahasiswa Jurusan Manajemen Untuk Berwirausaha}

Berdasarkan tabel 5.9, dapat diringkaskan faktor-faktor yang dominan sebagai penentu minat mahasiswa jurusan manajemen untuk berwirausaha seperti pada tabel berikut :

Tabel 14. Faktor - Faktor Yang Dominan Sebagai Penentu Minat Mahasiswa Jurusan Manajemen Untuk Berwirausaha

\begin{tabular}{|c|c|c|l|}
\hline Atribut & Korelasi $(\mathrm{R})$ & Faktor & \multicolumn{1}{|c|}{ Keterangan } \\
\hline $\mathrm{V}_{7}$ & 0,821 & 1 & Keyakinan \\
$\mathrm{V}_{5}$ & 0,712 & 1 & Prestise \\
$\mathrm{V}_{15}$ & 0,696 & 1 & Pekerjaan orang tua \\
$\mathrm{V}_{3}$ & 0,624 & 1 & Tanggung jawab keluarga \\
$\mathrm{V}_{17}$ & 0,588 & 1 & Senang \\
$\mathrm{V}_{1}$ & 0,551 & 1 & Kebebasan \\
$\mathrm{V}_{23}$ & 0,517 & 1 & Kebijakan pemerintah \\
$\mathrm{V}_{13}$ & 0,517 & 2 & Kreatif \\
\hline $\mathrm{V}_{18}$ & 0,737 & 2 & Satar belakang kelurga \\
$\mathrm{V}_{16}$ & 0,735 & 2 & Pesaing \\
$\mathrm{V}_{20}$ & 0,668 & 2 & Suka Tantangan \\
$\mathrm{V}_{9}$ & 0,634 & 2 & Kesempatan \\
$\mathrm{V}_{24}$ & 0,630 & 2 & Inovatif \\
$\mathrm{V}_{10}$ & 0,567 & & \\
& & 3 & Pendapatan \\
$\mathrm{V}_{2}$ & 0,780 & 3 & Kompetensi \\
$\mathrm{V}_{6}$ & 0,751 & 3 & Bertanggung Jawab \\
$\mathrm{V}_{11}$ & 0,689 & 3 & Modal \\
$\mathrm{V}_{21}$ & 0,682 & 3 & Optimis \\
$\mathrm{V}_{8}$ & 0,603 & 3 & Kreatif \\
$\mathrm{V}_{13}$ & 0,518 & 3 & Kebijakan pemerintah \\
$\mathrm{V}_{23}$ & 0,508 & 4 & Kepuasan \\
\hline $\mathrm{V}_{4}$ & 0,752 & 4 & Pengalaman \\
$\mathrm{V}_{12}$ & 0,721 & Informasi \\
$\mathrm{V}_{22}$ & 0,610 & Peluang \\
$\mathrm{V}_{19}$ & 0,575 & & \\
\hline
\end{tabular}

Sumber: Hasil Pengolahan Data

Berdasarkan tabel di atas menunjukkan bahwa dari 24 faktor yang dominan sebagai penentu minat mahasiswa jurusan manajemen untuk 
berwirausaha dari Faktor 1 : Keyakinan, Prestise, Pekerjaan orang tua, Tanggung jawab keluarga, Senang, Kebebasan, Kebijakan pemerintah dan Kreatif ; Faktor 2 : Latar belakang kelurga , Status Sosial, Pesaing, Suka Tantangan, Kesempatan dan Inovatif ; Faktor 3 : Pendapatan, Kompetensi, Bertanggung Jawab , Modal, Optimis, Kreatif dan Kebijakan Pemerintah ; Faktor 4 ; Kepuasan, Pengalaman, Informasi dan Peluang.

\section{Pembahasan}

Pembahasan hasil penelitian ini dilakukan berdasarkan hasil analisis deskriptif dan hasil analisis faktor yaitu sebagai berikut:

1. Faktor Lingkungan. Titik (2006: 42) yang menyatakan salah satu faktor pendorong seseorang untuk berwirausaha yaitu The parental refugee yang menjelaskan banyak individu memperoleh pendidikan dan pengalaman dari bisnis yang di bangun keluarganya, lingkungan keluarga sangat mempengaruhi minat berwirausaha seseorang, lingkungan keluarga mahasiswa yang familiar dengan wirausaha juga akan menyebabkan mahasiswa tersebut akan tertarik dengan wirausaha, hal ini sependapat dengan penelitian Muladi (2011 :119) yang menyatakan lingkungan keluarga, lingkungan sekolah dan lingkungan pergaulan memberikan kontribusi yang tinggi terhadap minat siswa SMK di kota Medan untuk berwirausaha setelah lulus. Jadi dapat di simpulkan lingkungan keluarga dan lingkungan sekitar mahasiswa baik tempat tinggal atau pergaulan yang memberikan mahasiswa kesempatan praktek wirausaha menjadi faktor penentu minat mahasiswa dalam berwirausaha.

2. Faktor Harga diri. Harga diri merupakan sifat yang memotivasi mahasiswa agar selalu menjadi lebih baik. Menurut Utin (2011 :139) berwirausaha di gunakan untuk meningkatkan harga diri seseorang, karena dengan usaha tersebut orang akan memperoleh popularitas, menjaga gengsi dan menghindari ketergantungan terhadap orang lain. hal ini dapat di katakan bahwa mahasiswa menginginkan kebutuhan akan prestasi yang membuat orang-orang tidak memandang mereka rendah, komitmen yang dalam diri setiap mahasiswa juga harus diperhitungkan dalam menentukan minat berwirausaha.

3. Faktor peluang. Peluang merupakan kesempatan-kesempatan yang didapat oleh seseorang atau juga kemampuan melihat sesuatu dalam perspektif yang berlainan dalam satu waktu, seorang yang berwirausaha tentu sangat membutuhkan peluang ini, dimana hal in sependapat dengan Titik (2006:46) dalam jurnal penelitianya yang 
menyatakan pendorong para responden untuk berwirausaha yaitu jiwa kewirausahaan terutama untuk memanfaatkan peluang dan prospek wirausaha yang cerah. dengan mengetahui peluang yang bagus dan peluang-peluang yang dia miliki baik berupa modal ataupun ide yang belum ada di pasar akan memancing minat mahsiswa untuk mengambil kesempatan itu.

4. Faktor Kepribadian. Seorang wirausaha membutuhkan kepribadian yang khas agar mendukung minat berwirausaha seperti kepemimpinan sehingga menjadikan factor kepribadian menjadi penentu minat mahasiswa berwirausaha hal ini sejalan dengan penelitian yang di lakukan oleh Dyah (2007) yang menyatakan kepribadian mempengaruhi minat mahasiswa untu berwirausaha, lebih lengkapnya dijelaskan dalam Alma (2007 :13) yang menyatakan bahwa salah satu faktor yang mendorong mahasiswa berwirausaha yaitu personal atau disebut juga kepribadian. Oleh karena itu dalam kewirausahaan di perlukan kepribadian yang baik, sehingga menciptakan kepribadian yang produktif yang nantinya akan berfungsi dalam mengembangkan wirausaha.

5. Faktor Pendapatan dan percaya diri. Pendapatan memang salah satu penentu minat untuk berwirausaha, laba yang tinggi merupakan alasan untuk seseorang berwirausaha, seperti penelitian yang di kemukakan Utin $(2011$ :138) pendapatan yang tak terbatas sangat menarik minat seseorang untuk menurut berwirausaha, besar kecil pendapatan yang di dapat oleh wirausaha sangat tergantung dari hasil usaha atau kerja yang di lakukan. Dan untuk rasa percaya diri hal ini sependapat dengan Robert (2008 : 7) bahwa para wirausaha cenderung sangat yakin terhadap kemampuan mereka untuk sukses dan mereka cenderung optimis terhadap peluang kesuksesan.

\section{KESIMPULAN DAN SARAN}

\section{Kesimpulan}

Berdasarkan hasil penelitian dapat disimpulkan bahwa dari 24 faktor yang yang dominan sebagai penentu minat mahasiswa Jurusan Manajemen untuk berwirausaha adalah : Faktor 1 : Keyakinan, Prestise, Pekerjaan orang tua, Tanggung jawab keluarga, Senang, Kebebasan Kebijakan pemerintah dan Kreatif ; Faktor 2 : Latar belakang kelurga, Status Sosial, Pesaing, Suka Tantangan, Kesempatan dan Inovatif ; Faktor 3 : Pendapatan, Kompetensi, Bertanggung Jawab , Modal , Optimis, Kreatif 
dan Kebijakan Pemerintah ; Faktor 4 ; Kepuasan, Pengalaman, Informasi dan Peluang.

\section{Saran}

Peneliti hanya meneliti 24 faktor selanjutnya diharapkan menambah variabel yang akan dijadikan variabel penelitian yang diduga mempengaruhi minat mahasiswa berwirausaha. Penelitian ini dapat dijadikan acuan untuk meningkatkan kualitas sumber daya manusia melalui wirausaha. Untuk penelitian selanjutnya diharapkan peneliti dapat memperluas responden yang dijadikan sampel penelitian .

\section{DAFTAR PUSTAKA}

Ani Murwani Muhar, (2013) Faktor Penentu Minat BerwirausahaDi Kalangan Mahasiswa Perguruan Tinggi Neger (Studi Perbandingan Mahasiswa USU, UNIMED, dan IAIN), Jurnal Keuangan dan Bisnis, Vol. 5, No. 1

Alma, Buchari, 2007. Kewirausahaan, Bandung, Alfabeta. ,2010. Kewirausahaan. Bandung: Alfabeta.

Fuadi, Iski Fadli "Hubungan Minat Berwirausaha dengan Prestasi Praktik Kerja Industri Siswa kelas XII Teknik Otomotif SMK Negri 1 Adiwerna Kabupaten Tegal.” Jurnal PTM Volume 9,Desember 2009, hlm 92-98.

Hair, J.F., Anderson, R.E., Tatham, R.L., dan Black, W.C. (1998), Multivariate Data Analysis, New Jersey: Prentice-Hall.

Muladi Wibowo.2011, "Pembelajaran kewirausahaan dan minat wirausaha lulusan SMK," jurnal ekspansi volume 6 nomor 2 edisi september 2011.

Nasution, Arman Hakim dkk. (2001).Membangun Spirit Entrepreneur Muda Indonesia, Suatu Pendekatan Praktis dan Aplikatif. Gramedia, Jakarta.

Nugroho J, setiadi. 2003. Perilaku konsumen konsep dan implikasi untuk strategi dan penelitian pemasaran .Jakarta: Prenada Media.

Hisrich. D.Robert, Michael P.Peters dan Dean A. Shepherd. 2008. Kewirausahaan. Terjemahan Chriswan Sungkono dan Diana Angelica, Jakarta Salemba Empat.

Sugiyono, 2005, Pengujian Reliabilitas Dengan Internal Consistency, Penerbit Yogyakarta

Suryana. 2008. Kewirausahaan. Salemba empat. Jakarta.Yogyakarta: Fakultas Ekonomi Universitas Gajah Mada.

Titik Purwinarti. 2006. "Faktor Pendorong Minat Berwirausaha (Studi lapangan terhadap polieknik Negeri Jakarta)," jurnal penelitian ekonomi dan bisi vol 5 no 1 maret 2006:39-46.

Utin Nina Hermina.dkk. "Pengaruh mata kuliah kewirausahaan terhadap minat mahasiswa menjadi wirausaha pada program studi administrasi bisnis politeknik negeri Pontianak." jurnal eksos juli 2011: hal 130-141.

Yulia dan Endah Kusrini "Analisis karakteristik Mahasiswa dan Faktor-Faktor yang berpengaruh terhadap kepemilikan Usaha Mandiri Mahasiswa ITS" Jurnal penelitian dan Evaluasi. 4(III). Hlm .94- 110.

http://digilib.its.ac.id/ public /ITS -Undergraduate-13441-Paper.pdf 